Primož Jurko

University of Ljubljana

Slovenia
2015, Vol. 12 (2), 193-209(244) revije.ff.uni-lj.si/elope

doi: 10.4312/elope.12.2.193-209

\title{
Evaluative Meaning in Translation
}

\begin{abstract}
Evaluative meaning is frequently understood as a form of connotation, pertaining to single lexical items. However, the term has recently been applied also to longer stretches of text, spanning several words. The paper generally deals with the latter aspect and provides a corpus-driven analysis of several Slovene and English phrases that may appear semantically neutral, yet turn out to be heavily non-neutral in terms of their semantic properties. After a short introduction of the main approaches to the topic, including its dilemmas, the paper focuses on the L1-into-L2 translation of such strings, with particular emphasis on proper rendering of the evaluative meaning. While further research is warranted into the matter, the work presented here attests to the complex and ubiquitous nature of the Sinclairian extended unit of meaning.
\end{abstract}

Keywords: semantic prosody; translation; lexicology; corpus linguistics

\section{Vrednotenjski pomen $\mathbf{v}$ prevajanju}

\section{POVZETEK}

Članek se ukvarja z vrednotenjskim pomenom, in sicer ne le z onim, ki izhaja iz konotacije posameznega leksema, temveč pretežno s tistim, ki je frazeološko pogojen in se pripisuje daljšim nizom besed. Podana je korpusno gnana analiza nekaterih slovenskih in angleških nizov, za katere se zdi, da se ne nagibajo k bodisi pozitivnemu ali negativnemu vrednotenju, pa se vendarle izkažejo za močno obremenjene s t.i. semantično prozodijo. Potem ko so prikazani glavni pristopi k obravnavi semantične prozodije, se članek osredotoči na prevajanje večbesednih nizov iz maternega $\mathrm{v}$ tuj jezik v luči ustreznega prenašanja prav te komponente. Prispevek pritrjuje Sinclairovi tezi o obstoju razširjenih pomenskih enot, ki bodo nedvomno tudi vnaprej pomemben predmet raziskovanja korpusnega jezikoslovja.

Ključne besede: semantična prozodija; prevajanje; leksikologija; korpusno jezikoslovje 


\section{Evaluative Meaning in Translation}

\section{Introduction}

The evaluative part of meaning, perhaps the most elusive meaning component of all, successfully avoided the limelight of lexicological attention until 1993, when the term semantic prosody was first used by Louw $(1993,157)$. He used it to refer to the fact that meaning in certain word combinations frequently spills over from one component to the other and frequently dominates the meaning of the entire combination. In order to clarify what we will talk about in this article let us use Stubbs's example $(1995,2)$ of the verb break out, which he found to often collocate with nouns such as violence, riots, war, sweat, disagreement, storm of protest. Obviously, there is a common semantic denominator present in all these nouns, which can be summed up as an unfavorable or unpleasant process. The spill-over of the negative meaning embodied in the nouns, it is claimed, has affected the verb break out, which can therefore hardly be used with inanimate nouns of a neutral or positive meaning disposition (the exceptions being peace with 40 hits and applause with 21, see Figure 1 for top 20 collocating nouns in the Corpus of Contemporary American). ${ }^{1}$

\begin{tabular}{|c|c|c|c|}
\hline 1 & $\bigcap$ & WAR & 654 \\
\hline 2 & $\Pi$ & FIRE & 193 \\
\hline 3 & $\Pi$ & FIGHT & 151 \\
\hline 4 & $\Pi$ & FIGHTING & 121 \\
\hline 5 & $\Pi$ & VIOLENCE & 85 \\
\hline 6 & $\bigcap$ & SWEAT & 77 \\
\hline 7 & $\Pi$ & RIOTS & 75 \\
\hline 8 & $\Pi$ & FIGHTS & 74 \\
\hline 9 & $\Pi$ & WORLD & 54 \\
\hline 10 & $\Pi$ & TIME & 46 \\
\hline 11 & $\Pi$ & FIRES & 44 \\
\hline 12 & $\Pi$ & PEACE & 40 \\
\hline 13 & $\Pi$ & CONFLICT & 35 \\
\hline 14 & $\Pi$ & RIOT & 31 \\
\hline 15 & $\Pi$ & RIOTING & 31 \\
\hline 16 & $\Pi$ & SHOOTING & 29 \\
\hline 17 & $\Pi$ & FACE & 28 \\
\hline 18 & $\Pi$ & ARGUMENT & 27 \\
\hline 19 & $\Pi$ & HOSTILITIES & 27 \\
\hline 20 & $\square$ & SCUFFLE & 26 \\
\hline
\end{tabular}

FigURE 1 . Top 20 collocating nouns preceding break out from COCA.

The term semantic prosody is just one of many that has been used to refer to evaluative meaning; others include attitudinal meaning, pragmatic meaning, connotation, collocational prosody and discourse prosody. This variety of terminology is a reflection of two important facts: firstly, the topic means many things to many people, and secondly, because of its multi-faceted nature, the topic is hard to pin down in scientific terms. Rather than provide an in-depth survey of the numerous authors and their pros and cons in choosing their criteria and terminology, this introduction will focus on those that are most relevant to the approach applied in our study. For a comprehensive take on the topic, the reader is best advised to turn to Stewart's monograph (2010), and Šorli (2014) for a cross-linguistic view with special emphasis on lexicographical implications.

\footnotetext{
Corpus of Contemporary American (COCA), (Davies 2008), available at http://corpus.byu.edu/coca/.
} 
Although all the items of the nomenclature listed above are still in use, it is the term of semantic prosody that appears to be gaining ground in most current research and that will be used in this text as well.

\section{Semantic Prosody}

\subsection{Clearing the Field}

The role and significance of language corpora simply cannot be overstated in contemporary linguistics in general and lexicology in particular. Before the advent of corpus linguistics many (or even all) phenomena of the real linguistic usage were no more visible than the tip of an iceberg. Some scholars were better than others at estimating (and frequently) guessing the size, shape and nature of whatever language-related problem they were observing. What is arguably the farthest-reaching consequence of large databases realistically mimicking language usage is the insight they yield into patterns of co-occurrence. The first kind of word combinations that was made palpable by language corpora was collocations. While it is true that they were announced as early as in the 1930s in the work of Porzig (1934), and some two decades later 'discovered' and christened by Firth (1957), it is largely undisputed that it was only John McHardy Sinclair in the late 1980s who was able to see the phenomenon of collocation as a whole. His editorial work on the first corpus-based EFL dictionary COBUILD (Sinclair 1987) was a pioneering breakthrough in several ways, and one of the key features of the COBUILD dictionary was precisely the much improved presentation and treatment of collocations in comparison to other EFL dictionaries of the time. What Sinclair had and Porzig and Firth did not is a computer loaded with a corpus and a set of software tools that enabled him to peek into it. The advent of corpus linguistics in the realm of EFL lexicography at the end of 1980s brought about revised or new editions of virtually all important dictionaries of the field, which have been corpus-based ever since: e.g. the 4th edition of the Oxford Advanced Learner's Dictionary of Current English (Cowie 1989), the 1st edition of the Cambridge International Dictionary of English (Procter 1995) and the 3rd edition of the Longman Dictionary of Contemporary English (Summers 1995).

But collocations were only the beginning: as corpora grew in size and accessibility, so did the degree of complexity and invisibility of discovered lexical patterns. While collocations can be seen as the basic patterns of language in use, a more abstract feature of a string of items can be "identified from the generalization across collocations" (Ellis, Frey, and Jalkanen 2009, 90). This abstract feature has been dubbed semantic prosody and the concept itself has met with a wide response, not all of which has been favorable. One of the harshest criticisms came from Whitsitt (2005), who described semantic prosody as a brainchild of overzealous corpus linguists, and also addressed both the lack of and the need for a firm methodological approach to the topic. One of the main points of Whitsitt's text refers to the issue whether semantic prosody is a phenomenon arising from a word's connotation (i.e. from the associative meaning of one word) or whether it is something that applies to the phrase as a whole. The view that connotation lies at the core of semantic prosody is supported by several scholars. Partington $(2004,136)$, for one, has found evidence that the verb to happen "has a bad semantic prosody" and "is primed to occur with unpleasant events" as showcased in the examples below:

If an accident happens as a result of driving which deviates from the proper standard...

She then went to bed feeling more relaxed, but after a while felt unwell and was soon sick. This happened several times during the night. 
According to Partington (2004) the verb to happen has suffered from being repeatedly used with nouns denoting unpleasant events and processes. The arising bad semantic prosody for him is thus the result of the spillover of the negative meaning of the collocating nouns (in the first example) and wider context (in the second example) and is in this respect close to connotation. We can observe a similar relationship with the Slovene prima facie translation equivalent verb zgoditi se that has the following top-10 list of nouns appearing as subjects: nesreča, čudež, krivica, incident, tragedija, preobrat, umor, katastrofa, rop, premik (Eng. accident, miracle, injustice, incident, tragedy, turn, murder, catastrophe, robbery, move/movement). The list is dominated by negative nouns, but not every single noun is negative: it also includes three nouns that do not denote unpleasant events: čudež, preobrat, premik. The same applies to happen, where miracle and magic are also found among the top collocates. It is interesting to note, however, that in Slovene, zgoditi se is very different from its denotative near-synonym pripetiti se: the latter bears a much heavier burden of negative connotation arising from its combinations with nouns referring to negative or unpleasant events. The list of collocating nouns for pripetiti se is self-explanatory: nesreča, nezgoda, nerodnost, incident, dogodek, neprijetnost, spodrsljaj, nev̌̌ečnost, napaka, tragedija (Eng. accident, mishap, awkwardness, incident, event, discomfort, slip, inconvenience, mistake, tragedy). The only neutral term in the list appears to be dogodek; however, even this one is in most cases preceded by the adjectives tragičen and neljub (Eng. tragic, undesirable). In a similar manner Partington (2004, 133) has examined the semantic prosodies of several verbs belonging to the same semantic group (or in his terms "the happen words": happen, occur, come about, take place, set in) and has determined that they are about twice as likely to be used in negative contexts than in positive. Future work will show whether the Slovene verbs belonging to this semantic group all share the strongly dominant traits found in the above zgoditi se and pripetiti se (some that come to mind are primeriti se, dogoditi/dogajati se, prigoditi se, all expressing the same basic meaning to happen in English).

Unlike Partington, who sees semantic prosody as something related to the meaning (connotation) of a single word, there are numerous scholars who subscribe to a different point of view. Rather than a property of a word, in their view semantic prosody is construed as functional meaning that is phrasal in nature and related to the text it belongs to. Sinclair (1996 and 2004), Louw (2000), Hunston (2007) and Philip (2009) represent this line of reasoning, which will also be applied in our analysis below. It will be appreciated that semantic prosody frequently arises in the meaning forming process when the speaker wishes to add some color to his/her text that is not explicitly lexicalized: one way of achieving this is to select larger chunks of texts that contain the desired nuance in the form of pragmatic meaning. While some of this pragmatic meaning doubtlessly stems from connotation, we will attempt to show that semantic prosody is part of any communication and is present even when there is arguably no connotation to speak of.

This in turn means that to uncover semantic prosody quite often wider co-text will have to be studied in order to establish the big picture of the entire communicative situation (Philip 2009). Semantic prosody can therefore only be studied in language that is doing what it is supposed to do - fulfilling the need to convey a message in real life. In structuralist terms semantic prosody is thus necessarily part of parole, while connotation forms part of an item's secondary meaning, is embedded in a speaker's mental lexicon and is psychological in nature, as observed by Šorli $(2014,113)$. The latter claim is also reflected in the fact that connotation is not uniform across language users, but varies from speaker to speaker. On the other hand, semantic prosody relies on convention to a much larger degree and as Philips $(2009,15)$ observes "novel, unfamiliar and/or idiosyncratic phrases cannot exploit a semantic prosody because semantic prosodies are tied to recurrent patterns, and novel phrases by definition have none" (my emphasis). 


\subsection{Rather Bad than Good?}

In line with the above observations of semantic prosodies of the verbs happen and zgoditi se it would be possible to speculate that communicating bad news is more important to the human race than relating good news is: a quick glance at the news headlines at any time is very likely to reveal items similar to those found on the Guardian's homepage: crash, arrest, risk, sinister, threat, cancer (http://www.theguardian.com/uk, 25 March 2015). Partington (2004, 144) seems to concur with this by positing that members of our species may "have a greater tendency or need to communicate to each other the "bad things' which happen in life and this could be reflected in texts". Possibly this bias to the negative side of the spectrum could even be traced back to the origins of language in humans, when the so-called homo loquens emerged as it is estimated by anthropological linguists anywhere between 100,000 BC and 30,000 BC. The importance of speech development is seen by many researchers as crucial in raising the chances of survival of the species, because it made possible the extension, structuring and maintenance of social relationships for large populations (Lefebvre, Cohen, and Comrie 2013, 82). Arguably communication of bad or threatening situations was a top priority for our forebears, and the ability of early humans to transmit such information from one generation to the next represented a quantum leap in terms of species development. Stretching the analogy of DNA in Morley and Partington (2009), ${ }^{2}$ this could explain how the evaluative element became an essential part of the DNA of any language on the planet and it should not come as a surprise that mostly items sharing negative semantic prosody have been discovered and researched so far. However, it remains to be seen whether future research will provide a more satisfactory and deeper grounded explanation of the negative dominance observed in semantic prosody so far, until then these ideas should be taken purely hypothetically.

Whatever the origins of the negative tendency of semantic prosody may be, the tendency is reflected in lexical items that have so far been studied in relation to semantic prosody (McEnery, Xiao, and Tono 2006, 84). The items can be summed up as being predominantly (but not exclusively) negative: happen, set in, cause, commit, peddle, peddler, dealings, end up verbing, a recipe for, get oneself verbed, fan the flame, signs of, ripe for, underage, teenager(s), sit through, bordering on. The list of items showing negative semantic prosody was expanded by Šorli (2012): situation, to equate and the grass is greener. The list is far shorter on the other end of the spectrum: so far only provide and career have been shown to have positive semantic prosody. There are estimates that negative semantic prosody is about twice as frequent as the positive (Louw 1993). However, this ratio may turn out to be much higher in favor of the negative side and remains to be attested in future work.

\section{Translation and Semantic Prosody}

The difficult task of coping with semantic prosody in the translation process has been addressed several times in the last decade. When one considers that English is the language where the phenomenon was first discovered, it is hardly surprising that in all translation-oriented studies conducted so far it is featured as one of the languages. Here is my attempt at an updated (but not exhaustive) list of works, which deal with English and another language:

- Italian: Partington (1998), Tognini-Bonelli (2001), and Philip (2003);

- Portuguese: Berber Sardinha (2000), and Lopes (2011);

Morley and Partington refer to the metaphorical sense of DNA from biogenetics several times in their text. To sum up, they claim that semantic prosody is "in the DNA of the [lexical] item". 
- Chinese: McEnery, Xiao and Tono (2006), and Wei and Li (2014);

- Danish: Dam-Jensen and Zethsen (2008);

- Spanish: Munday (2011), and Bayón García (2013);

- French: Kübler and Volanschi (2012), and

- Slovene: Gabrovšek (2007), Šorli (2012), Šorli (2014), and Jurko (2012).

The focus of the above studies covers a wide range, from establishing differences in prosodies across near-synonyms, to questioning translator awareness of the issue of semantic prosody. Two of these (Kübler and Volanschi 2012; Bayón García 2013) deal with changes in semantic prosody not only across languages, but also changes that have been reported in LGP and LSP (language for general and special purposes, respectively). For instance, Kübler and Volanschi (2012) analyzed the English verb to commit in LGP and compared it to its French face-value translation equivalent commettre. In the LSP domain their objective was to test whether the well-documented negative semantic prosody of the English to cause and its French counterpart can also be detected in comparable LSP corpora. They have found that semantic prosody is very likely to undergo a smoothing process both in translation (English into French), as well as in passing from LGP to LSP. Also, they have confirmed Hunston's observation (2007) that in LSP semantic prosody is limited to effects on human beings (e.g. in LSP "may cause lateral motion" is smoothed to "peut générer des mouvements latéraux", but with humans "eruptions have caused deaths" remains "[eruptions] avaient causé des morts"; Kübler and Volanschi 2012, 130). Another interesting finding is the translator's awareness of an item's LGP-based semantic prosody, which may lead to over-cautious prosody-smoothing translations when that item is used in LSP discourse.

Rather than LSP-related issues, in the coming section we will be looking at LGP in translation from Slovene into English. In particular, we will focus on lexical items (or rather extended units of meaning) that at first glance have no obvious semantic prosody, yet are not selected randomly in the discourse, as will be shown.

\section{Methodology}

The Slovene items were queried and analyzed in the Fidaplus corpus, containing 738 million words collected between 1990 and 2006 (freely available at http://www.fidaplus.net). In order to analyze the collocational behavior of selected items the Sketch Engine (Kilgarriff et al. 2014, henceforth $\mathrm{SkE}$, available at http://the.sketchengine.co.uk/) software package was used. Crosschecking of less frequent Slovene items was done in the larger and more up to date Gigafida corpus of 1.2 billion words collected between 1990 and 2011 (freely available at http://www.gigafida.net).

On the English side queries were run in the 450 million Corpus of Contemporary American English (Davies 2008, henceforth COCA, available at http://corpus.byu.edu/coca/).

The analysis of meaning of Slovene and English items is based on the five-component model as proposed by Philip (2009) and applied by Šorli (2014). Philip has expanded Sinclair's (1998) quadripartite model of the extended unit of meaning. The four Sinclairian components of the model are collocation, colligation, semantic preference and semantic prosody, to which Philip has added a fifth category, namely that of semantic association (2009, 4). However, the category of semantic association has only been analysed in Slovene units, and no attempt was made to determine it in their English counterparts. The reason for this one-sidedness is clear from the very definition of semantic association, which is according to Philip $(2009,4)$ "describing secondary 
meanings - associations, evaluation and connotations - which are fundamentally psychological in nature and therefore not necessarily shared by all members of a speech community". As a nonnative speaker of English I am in no position to make any claims in this respect and will therefore refrain from doing so. To avoid any confusion, let it be clarified that Sinclair also mentions five elements in his work $(1998,14)$, one of which, however, is the core item itself. A detailed explanation of the components is given in Philip (2009). Space constraints do not permit more than an outline of semantic preference and semantic prosody.

Semantic preference can be broadly defined as the fact that some lexical items predominantly occur in patterns with other items belonging to a certain semantic field. Philip used the example to catch in the act and determined its semantic preference for the semantic field of "law-breaking, esp. theft; breaking of moral/professional codes of conduct" (Philip 2009, 9).

The fourth Sinclairian component of the unit of meaning is semantic prosody. It refers to the attitudinal or pragmatic function and is seen as crucial in the speaker's motivation for making the utterance in the first place. Semantic prosody and the core item itself are the obligatory parts of the unit of meaning, while the others are optional (Sinclair 1998, 15) and may or may not be present. To refer once again to Philip's example of catch in the act, she discovered the semantic prosody of "gloating over reported discovery of wrongdoing in progress; anticipation of the perpetrator's downfall” $(2009,9)$.

\section{Results}

\subsection{Example: labko + primeriti (310 Hits, 0.42 per Million Words in Fidaplus)}

The first extended unit consists of the modal adverb labko (Eng. may/can/could) followed by the reflexive verb lemma primeriti se (Eng. to happen/occur) in a window of up to 3 words. In terms

tudi hitro izgubi; in to se seveda lahko primeri tudi človeku, ki je bil za lastno korist državnega Leviatana. Vendar pozor: lahko se vam primeri , da med hlajenjem, denimo, v Blejskem jezeru

imeli tudi kamele. $\langle/ p\rangle\langle p\rangle$ Vse to se lahko primeri , če bomo imeli vroče in suho vreme ter

se slovnična ali pravopisna napaka lahko primeri vsakomur in da ni nihče nezmotljiv. A vendar

pravzaprav najhujša stvar, ki se lahko primeri moderni naciji, saj najlepše kaže stanje

rokovati zelo previdno in da se nesreča lahko primeri tudi starim mačkom, se je izkazalo v petek napora in volje, se na začetku kaj lahko primeri , da vaše roke nenadoma postanejo lahke

, se $v$ nasprotnem primeru lahko marsikaj primeri . Kako pravimo tistim, ki tako strmo nenehno

človeških žrtev ni bilo. Kdaj se lahko to primeri , pa si poglejte na kartah o stezah antilskih

sestavili enotno moštvo. Kaj lahko bi se primerilo, da bi kakšna od strankarskih opcij v resnici lotili svojih žrtev, saj se jim bo lahko primerilo, da bo ravno $v$ tistem trenutku prineslo lotili svojih žrtev, saj se jim bo lahko primerilo, da bo ravno $v$ tistem trenutku prineslo po vojni. To je spodrsljaj, ki se lahko primeri vsakemu. Takrat so na letališču Ewa pristajali milijonov SIT, kljub temu pa se lahko znova primeri, da bi se znašli v rdečih številkah, kot južnih in zahodnih vetrov ne bo, se lahko primeri , da bo december suh. $\langle/ p\rangle\langle p\rangle$ Letošnjemu " števil $v$ žepni računalnik. $\langle/ p\rangle\langle p\rangle$ Lahko se primeri , da otrok ni sposoben preiti na novo nalogo

lajajajo «. Tak spodrsljaj se kajpak lahko primeri tudi šolanemu slikarju ali črkostavcu.

glavo s tem. Če ne bodo pohiteli, se lahko primeri , da bodo naše visoke šole, kakršna je ljubljanska jugozahodnem delu Bolivije se lahko marsikaj primeri . Dežela je obdana z ognjeniki in skoznjo

Človek res nikoli ne ve, kaj vse se lahko primeri . No, roko na srce: " napadati « jih res

FIgURE 2. Sample page of concordances of lahko+primeriti from Fidaplus. 
of denotation the verb primeriti se is used to express events that occur unexpectedly, according to Slovar Slovenskega Knjižnega Jezika, the largest dictionary of Slovene. ${ }^{3}$

As far as collocation is concerned the top nouns co-occurring with the unit are zmešnjava, spodrsljaj, tlak, trup, zagon (Eng. mess/confusion, slip-up, pressure, trunk, momentum).

In terms of colligation the following patterns were observed:

- predominantly introduces an object clause (e.g. Kajti kaj hitro se labko primeri, da domnevni (aretirani) storilec...)

- frequently preceded by the intensifier $k a j$ (Eng. quite) and a personal pronoun in the dative (e.g. Sicer se nam kaj lahko primeri neokusno prodajanje zgodb...)

- frequently preceded by $b i$ (Engl. would/could) in past conditional statements (e.g. sicer bi se lahko primerila nesreča še komu).

Semantic preference of the unit arising from its collocates alone is rather vague: only the top two collocating nouns have a common semantic denominator, which is that of an undesirable event. However, quite frequently the collocators do not tell the whole story: as indicated above, for deeper insight into semantic properties of the unit one often has to consider longer stretches of co-text. After digging deeper into context it was found that a vast majority $(85 \%)$ of all occurrences in the corpus refer to an unfavorable event or process. Therefore we have posited a semantic preference of an 'unfavorable event or process'.

Semantic association of labko+primeriti se has been determined as 'an unpleasant or undesirable event that is possible' in utterances with a future reference. In utterances with a past time reference (evidenced as one of the most frequent colligation patterns - past conditionals) semantic association is that of 'an unpleasant or undesirable event that was (narrowly) avoided'. In order for the semantic association to reveal itself it was often necessary to examine quite long passages of co-text, since the limited space in a concordance line made it impossible to determine whether the author used the unit favorably, neutrally or unfavorably. Sometimes, however, the decision may depend on one's system of personal values even after consulting the big picture, which can be appreciated from the example below:

Eno takih vprašanj je zagotovo referendumska propaganda, ki ni posebej urejena in potemtakem tudi financiranje ni omejeno ali celo prepovedano, kot na primer velja za financiranje volitev. Zato bi se labko primerilo, hipotetično, da bi tudi skupina dobro organiziranih lezbijk iz tujine prispevala denar za referendum, na katerem bo odločeno, ali naj imajo ali ne pravico do umetne oploditve tudi zdrave ženske brez moža ali zunajzakonskega partnerja.

(Eng. One of these issues is referendum propaganda, which is not subject to any particular regulations or limitations or even bans in terms of financing, quite unlike election propaganda. So, hypothetically, it could happen that a group of well-organized lesbians from abroad would finance a campaign for a referendum on the right of single women to in-vitro fertilization.)

Semantic prosody of the unit is closely related to its semantic association. The functional part of the pragmatic meaning consists of an implied 'warning of a possible/avoided unfavorable

Available at http://bos.zrc-sazu.si/cgi/a03.exe?name=sskj_testa\&expression=primeriti+se\&hs=1. 
event'. The warning is frequently clearly expressed, e.g. as 'bog ne daj' (Eng. God forbid) in the following example:

Ko duriani zorijo, bog ne daj hoditi pod njimi ali morda celo poležavati v njih senčnem hladu, saj se labko primeri, da ti kakšen tak nekajkilski buzdovan trešči direktno dol na kepo.

(Eng. God forbid that you should walk under or even lie in the shade of durian trees when their fruit is ripe, for it can occur that one of these heavyweight maces falls right on your head.)

Summary of labko+pripetiti se:

Collocation: zmešnjava, spodrsljaj, tlak, trup, zagon.

Colligation: introduces object clause; preceded by $k a j$ and a personal pronoun in the dative; preceded by $b i$ in past conditionals.

Semantic preference: unfavorable events.

Semantic association: an unpleasant or undesirable event that is possible or was avoided.

Semantic prosody: warning of a possible/avoided unfavorable event.

\subsection{English Translation Candidates: may/can/could + bappen/ occur}

The first choice for the Slovene translator to make is between the verbs happen and occur, respectively. Most monolingual English college-size dictionaries define one in terms of the other (cf. reputable online sources like The free dictionary, ${ }^{4}$ while a good EFL dictionary (e.g. Longman Dictionary of Contemporary English, 5th ed.) will also tell you that both are used to express unplanned events, that occur is more formal and part of the academic vocabulary, while happen is preferred in everyday English. In actual fact, happen is about three times as frequent as occur in COCA (roughly 200,000 to 60,000 hits). This situation of having verbs with the same denotation, but different style (i.e. one quite common, the other rather formal) and frequency, appears to be very close to what we have in Slovene: zgoditi se is the common, (about 45 times!) more frequent one, while primeriti se is arguably more formal and virtually inexistent outside of written texts. ${ }^{5}$ However, as frequently happens, if something looks too good to be true, it usually is.

\subsubsection{Combinations with occur}

As far as collocation goes, there is considerable overlap between the combinations involving three different modal verbs. The tables below give you a comparison of the top five collocating nouns that precede may, can and could occur in a window of 4 words.

Available at http://www.thefreedictionary.com; the site gives single-search access to American Heritage Dictionary, Collins English Dictionary, Random House Kernerman Webster's College Dictionary as well as the Cobuild usage guide and several thesauri.

The verb primeriti se has only 1 hit in the corpus of contemporary spoken Slovene GOS, available at http://www.korpus-gos.net. 
TABLE 1. Top five collocating nouns preceding may occur, can occur and could occur from COCA.

\begin{tabular}{|l|l|l|l|}
\hline Rank & + may occur & + can occur & + could occur \\
\hline 1 & CHANGE & CHANGE & CHANGE \\
\hline 2 & PROBLEM & PROBLEM & PROBLEM \\
\hline 3 & EVENT & ERROR & SCENARIO \\
\hline 4 & EFFECT & COMPLICATION & DAMAGE \\
\hline 5 & INJURY & LEARNING & POSSIBILITY \\
\hline
\end{tabular}

The top two collocates are the same regardless of the modal verb: change and problem, followed by event, effect, injury, error, complication, learning, scenario, damage, possibility.

Colligation of the unit shows the following dominant patterns:

- sentence opening position (e.g. These changes can occur rapidly, so it is important to recognize which lake and food web characteristics influence);

- sentence closing position (e.g. I asked Peggy to speculate about why various levels of alignment may occur.);

- often precedes prepositions (e.g. Genocide could occur in Nazi Germany because part of the population...).

In terms of semantic preference no firm conclusions could be drawn, although a number of collocates do share the semantic component of an undesirable event: problem, injury, error, complication, damage. As a counter example there is the entirely positive learning, as well as several neutral-sounding nouns: change, event, effect, scenario, possibility. However, if the list of collocating nouns is expanded, it is impossible to miss nouns referring to medical conditions: death, infection, cancer, behavior, symptom, disease. Therefore we have established a semantic preference of 'undesirable events and medical conditions'.

When it comes to semantic prosody of the unit there are two possibilities that depend on the preceding modal: one is represented by the may/can occur combination, which has the prosody of 'an explanation for an unfavorable event beyond the speaker's control' (cf. examples above).

The second is the combination could occur, which is notably different in terms of semantic prosody. Largely owing to its future time reference, we have posited a semantic prosody of 'a warning of a possible unfavorable event in the future', which is evident in practically all concordances in Figure 3 below.

Summary of may/can/could + occur:

Collocation: change, problem, event, effect, injury, error, complication, learning, scenario, damage, possibility.

Colligation: sentence opening or closing position.

Semantic preference: undesirable events and medical conditions.

Semantic prosody: with may/can: an explanation for an unfavorable event beyond one's control; with could: warning of a possible unfavorable event in the future. 
economy - and President Obama is warning of a " tremendous blow " that could occur for millions of students in the form of an interest-rate hike in July. for the U.S. and Europe. Once adequate buffers became routine, another problem could occur: the buffers were now part of the pipe that TCP is so gooc Charnley 1997). Recent estimates indicate that sea-level rise of? $1 \mathrm{~m}$ could occur by the end of this century, potentially displacing $>20$ million people al slavery with familial dysfunction resonates with another postwar theory: maternal deprivation, which could occur whether a mother was absent or just it their chances of engaging in a variety of risk behaviors. Conversely, risk could occur among members of the periphery, and youths who have been home , and to find cognitive consensus, or revoke the decision psychologically, which could occur by using the avoidant or the spontaneous style. \# The result world? What about in the U.S.? There are 39 states where earthquakes could occur and 75 million people could be affected. And we do nt know anythinc higher ground to settle in for the night, remembered how quickly desert floods could occur, how his father would not drive across a dip in the road if the induced painful heating in the skin, chasing people away before any permanent damage could occur. "And the parboiled-looktag woman on that report? too distressing for patients or their families, the next step of psychosocial interventions could occur sooner. \# Evidence of improvement in rates and sevi the one on the right, initially identical, was raised in conditions that could occur in the Baltic Sea by 2100 . Ocean acidification is amplified in some coast: claim was not definite, nor did she propose a mechanism by which substitution could occur. Wolfe- Simon says her results were misinterpreted by other: of wear. The report warned that as a result, reactor core damage could occur much more often than expected. \# Fifteen years later, the problem appear fish are not sold or traded but still constitute a component of protein intake could occur at the time of licensing. \# Not unlike those directed toward mari \# Protests on a small scale are happening in China today. Major unrest could occur again if inflationary pressures persist, particularly if the price of nece

Figure 3. Sample random concordances of could occur from COCA.

In the continuation we will look at combinations with happen, the more frequent verb of the two.

\subsubsection{Combinations of may/can/could + happen}

Collocation patterns across the three combinations reveal at first glance the same collocating lemma: thing (see Table 2). A closer second look shows that the collocation with thing in any of the three combinations grossly outweighs all other collocators combined: in total, thing is found to precede $60 \%$ of all occurrences ( 872 of 1460 ), while the second most frequent collocator is lot and accounts for only $3 \%$ of all occurrences (48).

TABLE 2. Top five collocating nouns preceding may/can/could happen from COCA.

\begin{tabular}{|l|l|l|l|}
\hline Rank & + may happen & + can happen & + could happen \\
\hline 1 & THING & THING & THING \\
\hline 2 & PROCESS & LOT & {$[$ WAY] } \\
\hline 3 & {$[$ REASON] } & {$[$ WAY $]$} & DISASTER \\
\hline 4 & FEELING & MIRACLE & LOT \\
\hline 5 & ATTACK & ACCIDENT & CHANGE \\
\hline
\end{tabular}

The rest of the list shows very little overlap: lot and way appear in columns of can and could, respectively. However, way does not figure as a subject in any of the occurrences, in the same way as reason is never the subject of may happen: both nouns are merely used to express circumstances for something to happen as is the case in the examples below:

The only way that could happen is if the kids could take over a space...

\section{There are two reasons this may happen.}

An even more frequent type of collocator than the noun was the group of pronouns what, that and this: combined, they account for more occurrences (2068) than nouns (1460).

In terms of colligation the following patterns were found to be dominant:

- sentence final position for can happen (... was faring very poorly relative to Michael Dukakis until August, so a lot can happen.); 
- short sentence structures with that (That may happen to some.);

- questions with could happen (What's the worst thing that could happen?);

- adverbials of time following a lot can/could happen (A lot can happen in a year.).

When it comes to semantic preference of the unit no firm conclusions could be drawn from the list of collocating nouns. What does stand out, however, is the fact that the top collocating noun thing (semantically quite vague or even empty) is preceded by an adjective in the superlative in over $40 \%$ of all cases (quite obviously, perhaps, the most frequent being worst and best, respectively). This could lead to a tentative and rather vague semantic preference of 'evaluative adjective in the superlative'.

Turning to the pragmatic part, i.e. semantic prosody, the question is what do speakers want to express when they choose these word combinations? In the case of may happen the answer has to be a 'warning of a possible unfavorable event in the future'.

Semantic prosody of can/could happen is different: despite the predominant occurrence of the phrase the worst thing that could happen, the prosody is not that of a warning as above, but rather a 'realistic evaluation of a possible future development'. The speakers seem to be weighing the options at hand from either a pessimistic or an optimistic point of view, frequently to give the addressee (or themselves) a mental boost or support, like in the examples from COCA below:

\section{I don't know the worst thing that can happen in life, but it wouldn't be losing those things.}

\section{The worst thing that can happen is I fail and come back.}

However, when one looks at combinations with the second most frequent collocator, i.e. the noun lot, the semantic prosody of this unit is again that of a 'warning of a possible unfavorable event in the future'. Consider the random concordances in Figure 4, which all seem to have the 'warning' prosody.

can swing, in a Republican primary in the last two weeks a lot can happen, and the caucus works a lot like a primary. We know the people the vote, all bets are off, he said. " A lot can happen over a 10-month period on something like this. " \# How do we get this point. And I realize the margin of error -- and a lot can happen -- even a lot can happen between now and Tuesday. But in the event the margin of error -- and a lot can happen -- even a lot can happen between now and Tuesday. But in the event that the Republican candidate does win a lot could happen, yeah. Not a typical Sunday. A lot can happen. MS-DUNN: Yeah. MR-GREGORY: Let's play a little bit of politics , it was already tough. He has two years, and a lot can happen in politics in two years. First of all, we're already starting to never get that pig to sing!' The man repUed:? lot can happen in a year. The king might die. I might die. The pig from Chuff to Nrrilgan, and then from Nrrilgan to English. A lot can happen. " " Haven't seen this in any of the other Nrrilgan language translators weaken a bit. OK-that's-the-fir\# Keep in mind, there's a lot that can happen with these systems over the next 12 to 24 to 36 hours and you can season yet to be saying it's a really slow season. A lot could happen between now and the end of October. NEARY: Well, what does EI we Ve got a genuine alien spaceship to examine as well. A lot can happen in a year. Maybe we'll figure out how to- " There came a minutes. In two minutes we covered almost a thousand miles. A lot could happen. And there weren't any spacesuits for the rest of us.. 13. some of that variation. This is at least a reminder that a lot can happen in the fetal environment - that it's a very sensitive time. " Animal sent people out to take photographs, look for fingerprints? Because a lot can happen in a week. Do you know if something was done then? PARKER: -- those were friends of his, or acquaintances of his. A lot can happen between now and trial with those two. TED-WILLIAMS-CRIM: Well, certainly, a said, what, twenty minutes before she called the cops? A lot could happen in twenty minutes. One last shot at pseudo-politeness while she psyched herse seven to ten years is not unusual. In family time, a lot can happen in seven to ten years-childhood passes, people are born, get married, die ? Maybe I won't feel that way anymore. You know a lot can happen in a week. I can go right out here and jump out one of Has she got it knocked -- locked? BIDEN: No, a lot can happen in two and a half years, I would have to even though Im going their game plan, maybe changed their psyche. I mean, a lot can happen standing there waiting for your turn to get in the water. LAUER: As to home. " Siberian protectorate? Peter let it pass. A lot could happen in ninety-eight years. " Okay, " he said. " Can I get

FIGURE 4. Sample random concordances of the 'warning' prosody. 
Summary of may/can/could happen:

Collocation: thing, lot, miracle, accident, disaster, change.

Colligation: sentence final position for can happen, short sentence structures with that, questions with could happen, adverbials of time following a lot can/could happen.

Semantic preference: none detected (tentative: adjective in the superlative).

Semantic prosody: in may happen and a lot can/could happen: warning of a possible unfavorable event in the future; in can/could happen: realistic evaluation of options.

\section{Translation Considerations: Slovene into English}

The following lines offer a discussion of translation options with respect to the observed semantic prosody of the examined units. As a starting point let us look at these raw facts again:

- primeriti se is more formal and 45 times less frequent than zgoditi se in contemporary Slovene

- to occur is more formal and 3 times less frequent than to happen in contemporary English

The unit we examined consists of the Slovene adverb labko (denoting possibility or permission) and the verb primeriti se. At first glance the units lahko+primeriti se and may/can/could occur seem like a good pair of translation equivalents because of the roughly matching semantic preferences of unfavorable events (Slo. zmešnjava, spodrsljaj, napaka vs. Eng. problem, injury, error). Another strong point is the partly equivalent semantic prosody of a 'warning of a possible unfavorable event'. Indeed, many instances of Slovene concordances from Figure 2 can thus be successfully translated (lines 2, 9 and 10):

But beware: while swimming in Lake Bled it may occur that you...

When something like this could occur, it can be seen...

It could well occur that a party...

However, in several instances the translation with occur is not appropriate or the best one. In cases when:

(1) a broad range of options is possible (frequently signaled by Slo. marsikaj),

(2) there is a preceding superlative adjective, and

(3) the object in the dative is explicitly stated

an arguably better translation can be achieved by using happen (lines 3, 5 and 8 in Figure 2):

All this may happen if the weather is hot and dry...

... actually the worst thing that can happen to a modern nation...

... otherwise anything can happen.

To sum up the provisional guidelines: translation with may/can/could occur is appropriate in most cases when the unfavorable event is narrowed down by the context or has been previously defined. On the other hand, whenever a rather general unfavorable event is possible, and the preceding adjectives in the superlative, the translator is best served by picking happen. 
It is my teaching experience that Slovene translation students at university level tend to strongly favor the verb happen in their translations of primeriti se. The obvious reason for this appears to be the higher frequency. However, another important factor may well be its colligation pattern. The Slo. primeriti se can take an object in the dative:

\section{To se labko primeri vsakomur.}

... labko se vam primeri...

... nesreča se lahko primeru tudi starim mačkom...

In this respect a translation with happen is quite natural because it is far more frequently (about 50 times, according to COCA) found to precede an indirect object than occur (which, in turn, is not too surprising given that occur to somebody has the additional meaning of 'think of something'). Both factors combined undoubtedly account for the student's preference of happen over occur even in cases where the latter is a better choice, e.g.

Labko se primeri, da otrok ne bo sposoben preiti na novo nalogo...

It may occur that a child is not able to switch to the new task...

\section{Conclusion}

Despite the observed differences in the semantic prosodies of the English translation equivalents, it is a valid point that regardless of the translator's choice, the message of the source language text will be conveyed in the target language. In our case of the Slovene lahko+primeriti se and its English translation candidates may/can/could+occur/happen the basic meaning survives because the two verbs are so close in their respective denotations. So, what is the worst thing that can happen to a translation in the case of mismatched semantic prosodies? The main sacrifice is that of naturalness and fluidity of the target language text. While one can argue over the importance of accuracy of translation, it is also clear that disregarding pragmatic meaning in general and semantic prosody in particular can have disastrous consequences. Consider the examples:

\section{Negotiations eventually escalated into lasting peace.}

Everybody was having great fun, but the celebration was far from over.

While the first sentence can be expected to get the message across (one could also say the error is simply a wrong collocation), in the second sentence the effect is an awareness that something bad would follow. But what if the original was the following?

Vsi so se krasno zabavali, zabava pa še zdaleč ni bila končana.

Hence, semantic prosody really does matter. The consequences of mishandling it in translation are often not as dramatic as in the example above, but it is always there and should never be overlooked or ignored. 


\section{References}

Bayón García, María Cristina. 2013. “The Concept of 'Genetic Modification' in a Descriptive Translation Study (DTS) of an English-Spanish Corpus of Popular Science Books on Genetic Engineering: Denominative Variation, Semantic Prosody and Ideological Aspects of Translation Strategies." PhD Diss., University of Valladolid. http://uvadoc.uva.es/handle/10324/4183.

Berber Sardinha, Tony. 2000. "Semantic Prosodies in English and Portuguese." Cuadernos de Filogía Inglesa 9 (1): 93-110.

Cowie, Anthony P., ed. 1989. Oxford Advanced Learner's Dictionary of Current English. 4th edition. Oxford: Oxford University Press.

Dam-Jensen, Helle, and Karen K. Zethsen. 2008. “Translator Awareness of Semantic Prosodies.” Target: International Journal on Translation Studies 20 (2), 203-21. doi:10.1075/target.20.2.02dam.

Davies, Mark. 2008. The Corpus of Contemporary American: 450 million words, 1990 - present. http://corpus. byu.edu/coca/.

Ellis, Nick C., Eric Frey, and Isaac Jalkanen. 2009. "The Psycholinguistic Reality of Collocation and Semantic Prosody (1).” In Exploring the Lexis-Grammar Interface, edited by Ute Römer and Rainer Schulze, 89-114. Amsterdam: John Benjamins. doi:10.1075/scl.35.

Firth, John R. 1957. Papers in Linguistics. London: Oxford University Press.

Gabrovšek, Dušan. 2007. "Connotation, Semantic Prosody, Syntagmatic Associative Meaning: Three Levels of Meaning?” ELOPE 4 (1-2): 10-28. doi:10.4312/elope.4.1-2.9-28.

Hunston, Susan. 2007. “Semantic Prosody Revisited.” International Journal of Corpus Linguistics 12: 249-68. doi:10.1075/ijcl.12.2.09hun.

Jurko, Primož. 2012. “Collocation Errors in Encoding and Possible Cures: Dictionaries vs. Corpora.” In Dvojezična korpusna leksikografija: slovenščina v kontrastu: novi izzivi, novi obeti, edited by Mojca Šorli, 72-89. Ljubljana: Trojina, zavod za uporabno slovenistiko.

Kilgarriff, Adam, Vit Baisa, Jan Bušta, Miloš Jakubíček, Vojtěch Kováŕ, Jan Michelfeit, Pavel Rychlý, and Vit Suchomel. 2014. "The Sketch Engine: Ten Years On." Lexicography 1 (1): 7. doi:10.1007/s40607-014-0009-9.

Kübler, Natalie, and Alexandra Volanschi. 2012. "Semantic Prosody and Specialised Translation, or How a Lexico-Grammatical Theory of Language Can Help with Specialised Translation.” In Corpus Informed Research and Learning in ESP: Issues and applications, edited by Alex Boulton, Shirley Carter-Thomas, and Elizabeth Rowley-Jolivet, 103-34. Amsterdam: John Benjamins.

Lefebvre, Claire, Bernard Comrie, and Henri Cohen, eds. 2013. New Perspectives on the Origins of Language. Amsterdam: John Benjamins.

Lopes, Maria Cecília. 2011. "Tradução, padrôes e nuances: um estudo de Linguística de Corpus sobre diferentes prosódias semânticas na língua fonte e na língua alvo.” Revista Brasileira de Linguística Aplicada 11 (3): 747-72. doi:10.1590/S1984-63982011000300008.

Louw, Bill. 1993. "Irony in the Text or Insincerity in the Writer? The Diagnostic Potential of Semantic Prosodies." In Text and Technology: In Honour of John Sinclair, edited by Mona Baker, Gill Francis, and Elena Tognini-Bonelli, 157-76. Philadelphia: Benjamins. doi: 10.1075/z.64.11lou.

-. 2000. "Contextual prosodic theory: bringing semantic prosodies to life." In Words in Context: A Tribute to John Sinclair on His Retirement, edited by Chris Heffer and Helen Sauntson, 48-94. Birmingham: University of Birmingham

McEnery, Tony, Richard Xiao, and Yukio Tono. 2006. Corpus-Based Language Studies: An Advanced Resource Book. Abingdon: Routledge. 
Morley, John, and Alan Partington. 2009. "A Few Frequently Asked Questions about Semantic — or Evaluative - Prosody." International Journal of Corpus Linguistics 14: 139-58. doi:10.1075/ ijcl.14.2.01mor

Munday, Jeremy. 2011. "Looming Large: A Cross-Linguistic Analysis of Semantic Prosodies in Comparable Reference Corpora." In Corpus-Based Translation Studies: Research and Applications, edited by Jeremy Munday, Alet Kruger, and Kim Wallmach, 169-86. London and New York: Continuum.

Partington, Alan 1998. Patterns and Meanings: Using Corpora for English Language Research and Teaching. Amsterdam: John Benjamins.

—. 2004. "Utterly Content in Each Other's Company': Semantic Prosody and Semantic Preference." International Journal of Corpus Linguistics 9 (1): 131-56. doi:10.1075/ijcl.9.1.07par.

Philip, Gillian Susan. 2003. "Collocation and Connotation : A Corpus-Based Investigation of Colour Words in English and Italian.” PhD diss., University of Brighton. http://amsacta.unibo.it/2266/1/Thesis.pdf.

—. 2009. "Why Prosodies Aren't Always Present: Insights into the Idiom Principle." In Proceedings of the Corpus Linguistics Conference, edited by Michaela Mahlberg, Victorina González-Díaz, and Cathrine Smith. Liverpool: University of Liverpool.

Porzig, Walter. 1934. “Wesenhafte Bedeutungsbeziehungen.” In Beiträge zur Geschichte der deutschen Sprache und Literatur 58: 70-97.

Procter, Paul, ed. 1995. Cambridge International Dictionary of English. Cambridge: Cambridge University Press.

Sinclair, John McHardy. 1996. “The Search for Units of Meaning.” Textus 9 (1): 75-106.

—. 1998. "The Lexical Item.” In Contrastive Lexical Semantics, edited by Edda Weigand, 1-24. Amsterdam: Benjamins. doi:10.1075/cilt.171.02sin.

—. 2004. "Meaning in the Framework of Corpus Linguistics." Lexicographica 20: 20-32. doi:10.1515/9783484604674.20.

Sinclair, John McHardy, ed. 1987. Collins COBUILD English Language. Glasgow: Collins Publishers.

Stewart, Dominic. 2010. Semantic Prosody: A Critical Evaluation. New York: Routledge.

Stubbs, Michael. 1995. "Collocations and Semantic Profiles." Functions of Language 2 (1): 23-55. doi:10.1075/fol.2.1.03stu.

Summers, Della, ed. 1995. Longman Dictionary of Contemporary English. 3rd Edition. Harlow: Longman.

Šorli, Mojca. 2012. "Semantična prozodija v teoriji in praksi - korpusni pristop k proučevanju pragmatičnega pomena: primer slovenščine in angleščine." In Dvojezična korpusna leksikografjja: slovenščina v kontrastu: novi izzivi, novi obeti, edited by Mojca Šorli. Ljubljana: Trojina, zavod za uporabno slovenistiko.

—. 2014. "Pragmatični pomen v dvojezičnem slovaropisju." PhD diss., University of Ljubljana.

Tognini-Bonelli, Elena. 2001. Corpus Linguistics at Work. Amsterdam: John Benjamins.

Wei, Naixing, and Xiaohong Li. 2014. "Exploring Semantic Preference and Semantic Prosody across English and Chinese: Their Roles for Cross-Linguistic Equivalence." Corpus Linguistics and Linguistic Theory 10 (1): 103-38. doi:10.1515/cllt-2013-0018.

Whitsitt, Sam. 2005. "A Critique of the Concept of Semantic Prosody." International Journal of Corpus Linguistics 10 (3): 283-305. doi:10.1075/ijcl.10.3.01whi.

Xiao, Richard, and Tony McEnery. 2006. "Collocation, Semantic Prosody and Near Synonymy: A CrossLinguistic Perspective.” Applied Linguistics 27 (1): 103-29. doi:10.1093/applin/ami045. 


\section{List of Corpora}

COCA: Corpus of Contemporary American. Accessed June 12, 2015. http://corpus.byu.edu/coca/.

EnTenTen: English Web Corpus. Accessed June 12, 2015. http://the.sketchengine.co.uk/.

Fidaplus: korpus slovenskega jezika. Accessed June 12, 2015. http://www.fidaplus.net.

Gigafida: korpus slovenskega jezika. Accessed June 12, 2015. http://www.gigafida.net.

GOS: korpus govorjene slovenščine. Accessed June 15, 2015. http://www.korpus-gos.net. 